\title{
Learning Model Based on Local Wisdom to Embed the Ethics Land for Students
}

\author{
E. Ningrum \\ Department of Geography Education \\ Universitas Pendidikan Indonesia \\ Bandung, INDONESIA \\ epon.ningrum@yahoo.com
}

\begin{abstract}
- learning not only the process of acquiring new knowledge, but rather to embed values and moral. The ethics land relating with moral about the earth as a living space. Local wisdom is locally but global meaningful. In general, the purpose of this study is to embed the ethics land for student through the application of learning models based on local wisdom. Specifically, to design of learning based on local wisdom, implementing learning based on local wisdom and to embed the ethics land for students. The study design using classroom action research with the research setting to the students of class XI IIS 1 Laboratory School of UPI. Object of study is the design of learning, local wisdom, and the ethics land. The research instrument using a test, task, and the observation guide. Data Analysis using descriptive and statistics. Results of the study are: (1) Learning design to integrated local wisdom into teaching materials (2) Implementing learning using learning cycle models; and (3) the learners have an understanding concept about the ethics land.
\end{abstract}

Keywords-learning model, local wisdom, the ethics land

\section{INTRODUCTION}

Learning is a process of interaction of learners with educators and learning resources in a learning environment [1] to materialize educational interaction [2] to achieve the learning objectives [3]. Learning at the heart of education in order to produce an educated man and educated individuals through the process of empowerment and familiarization. Learning as a process of empowerment, acculturation, and changes, so that learners can be spread out the potential to become competence. Learners have the intelligence to think, act, and act (behave) as a result of learning. Thus, learning not only the process of acquiring new knowledge, but also the process of planting values, norms, ethics and morals as a manifestation of character education for students.

Behavioral learning theory emphasizes the importance of the environment in the formation and behavior change learners. Environment including learning components $[2,4]$ ), as a source of learning [5] as the actualization of learning outcomes [6], and affects behavior [7]). However, the phenomenon of global environmental degradation is continuing affect to the carrying capacity for learning, the balance of the ecosystem and the survival of living creatures. Therefore, it is important handlers and tackle environmental damage and impact. The more important thing is how to view and change behavior in interacting with the environment [8].
The land ethics is seen as one of the solutions in the face of environmental crisis through the eyes and behavior towards the earth and its contents based on moral and ethical. Based on the inclusivism view that humans are part of nature [9]. Humans have an obligation and responsibility to maintain a balance, integrity, stability, and harmony in their interaction with nature and other human beings. While the view of nature and anthropocentrism found it be an instrument for the fulfillment of human needs [8].

At the local level, the views of local wisdom of inclusivism may be applicable regionally but has a universal meaning. Local wisdom contained in the community can take the form of values, norms, customs, and knowledge as a guide to life continues to be preserved [10]. Local knowledge has ethical and moral significance with regard to the existence of nature and its contents. One of the functions of local wisdom is the conservation and preservation of natural resources [11]

The existence of environmental degradation, both carrying capacity and sustainability and balance, causing a global crisis. Treatment of these conditions have been carried out either through an institutional approach and practically a pragmatic society. Local knowledge has ethical and moral meaning underlying the behavior of the community in adapting and interaction with nature and the anticipation for the preservation of the earth as a living room. With, thus very important knowledge, attitudes, and behaviors responsible for the conservation of nature so that the earth carrying capacity is maintained as a living room.

Education has an important and strategic role in shaping the educated man who has a point of view that the earth as a moral subject and the human part of nature. Based on such a role, it is essential to the formation of learning-oriented knowledge, attitudes, and behaviors responsible for the earth, in addition to the achievement of academic competence. To that end, it is necessary to inculcate the land ethics learning model.

\section{RESEARCH METHODOLOGY}

The study used a qualitative approach with descriptive methods. In this study presents the results of a study of the literature on theories, concepts, and the opinion of the experts on learning models, local knowledge, and the land ethics, as well as the identification of competencies laden local wisdom and the land ethics. Furthermore, serve as the basis for formulating the learning model based on local wisdom to infuse the land ethics on the learner. The object of study is comprised of three aspects namely: local knowledge, the land ethics, and learning models. Researchers as the main instrument. The data were analyzed descriptively qualitative. 


\section{RESULTS AND DISCUSSION}

\section{A. Competence of Local Wisdom}

Based on the literature study, local wisdom grows and develop locally [12], can be ethics, morals, customs which have the advantage of local [10], and as the Code of Conduct in the ecological community [8]. The indigenous peoples, local knowledge is institutionalized, adhered to, and passed, as has the value of truth to adapt and interact with the environment. Moreover, it has the reliability to address the challenges and problems in the continuity of life. Thus, local wisdom to form a pattern of behavior in relation spatial harmony as a form of responsibility towards the preservation of the carrying capacity of the Earth as a living space for its residents.

Education sees the environment as a source of knowledge for the formation of local wisdom. Environmental elements interact to form a variety of events that provide the experience and be a source of knowledge for individuals and local communities. Interaction of environmental elements that produce objective and subjective environment environment. Environmental behavior (subjective environment) is a pattern of behavior that is formed based on the interaction between environmental elements.

The existence of the learning environment in perspective is one component of learning that contributes to the achievement of competence of learners [2]. Competencies that have linkages with local knowledge, particularly on the subjects contained in geography class XI classes that analyze mitigation and adaptation to natural disasters through the process of education, local knowledge, and the use of modern technology [13]. Competence can be achieved through a process of learning by using local wisdom as teaching materials. Local wisdom as one part of the teaching material has learning resources that come from the community. For that, the competence of teachers to develop teaching materials into teaching materials is very important.

\section{B. The Land Ethics in Learning}

Referring to several libraries, closely related to moral ethics [14], values and moral principles as the Code of Conduct [9]. The land ethics is closely related to moral and responsible behavior towards the Earth, because humans are part of nature and its contents [9]. Humans have an obligation to maintain harmonious interaction with nature and other living creatures as well as maintaining the stability of the earth's carrying capacity for the residents.

The land ethics with respect to the behavior of individuals, groups, communities, and nations based on moral or ethical oriented to the earth as a moral subject. The land ethics reflects behavior that maintains the integrity of the earth community as a part of nature, the stability of the earth's carrying capacity, and the harmony of human interaction with other human beings. There are three principles of the land ethics namely " A thing is right when it tends to preserve the integrity, stability, and beauty of the biotic community. It is wrong when it tends otherwise " [8]. All three of these principles need to be owned by every individual so that it will form a community, society, and the nation has a moral responsibility for the Earth as a living room.
Responsible behavior towards the earth will be formed through a learning process that imparts ethics earth on the learner. The learning process is characterized by the occurrence of functional interactions between components of learningoriented achievement of learning goals [14]. Learning is a process of empowerment and acculturation [15]. Learners have the potential of self-developed and enforced through a learning process to become a competence think, behave and act. Civilizing process instilling values, ethics, and morals to form behave in accordance with the norms. The ethical principles of the Earth can be introduced and familiarized with the learning process.

\section{Learning Model for Embedding Ethics Earth}

The function of the learning model is " each model of guides us as we design instruction to help students Achieve various objectives " [16]. Learning includes three activities, including planning, implementation, and assessment. The three activities based on the learning model selected. Choosing a learning model notice of material, the level of cognitive development of students, facilities and infrastructure, and learning media in order to achieve the effectiveness of learning [17].

The learning model to inculcate ethics with respect to the standards formulated earth content of the geography curriculum subject for education SMA / MA. Furthermore, the materials, the means infrastructures, and learning media, they become part of the instructional design to inculcate the land ethics. The learning model is: " the term teaching models refer to a particular approach to instruction that includes its goals, syntax, environment, and management system " [18].

The learning model based on local wisdom has six components, namely: rationale, competency to be achieved, syntax, measurable learning outcomes, impact Bridesmaids / long term, and instructional design. The learning model based on local wisdom to inculcate the land ethics visualized in the following figure 1 .

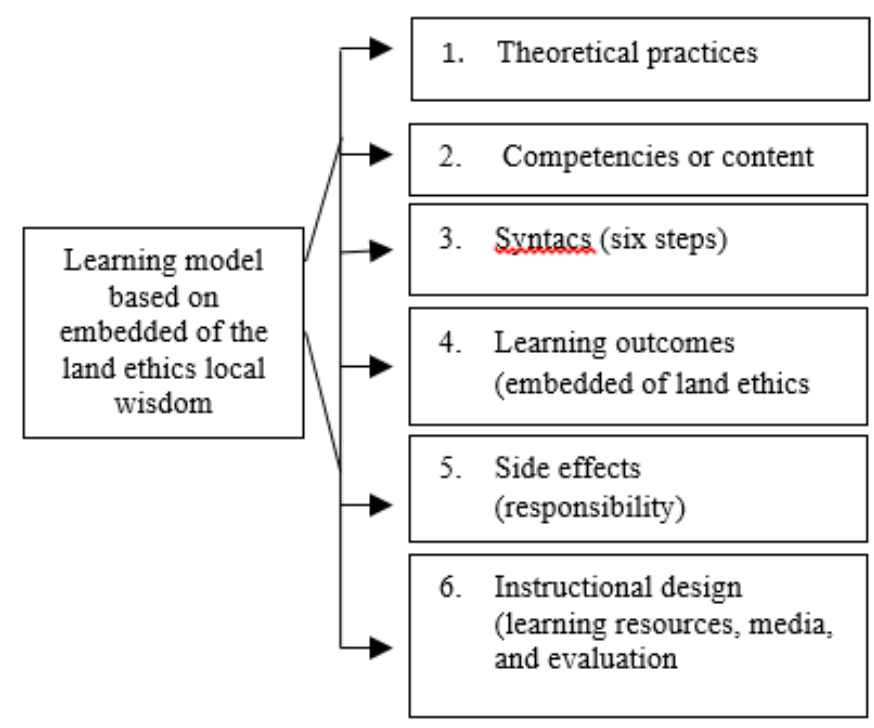

Fig. 1. Learning model based on embedded of the land ethics local wisdom (adapted from $[14,16]$ ) 
The rationale is based on a theoretical basis and practical. Cognitive learning theory (Piaget, Ausubel) stressed that learning is a mental process. Behavioral learning theory (Thorndike, Skinner), looked learning is a process of habituation to form habitual behavior. Learning theory of constructivism (Vygotsky) give priority to the principle of prior knowledge and conceptual-change in the learning process. Local knowledge can be ethical and moral behavior that guide the local community. A caring attitude and behavior are familiarized with the learning process.

Competence is the ability possessed by the process of development and development potential of learners. 'Competencies is the ability to understand local knowledge to analyze mitigation and adaptation to natural disasters. The syntax consists of six learning activities, namely: (1) orientation; (2) the presentation of the material; (3) identification of important concepts; (4) an understanding between concepts; (5) the application of the concept; and (6) of reflection.

The result of learning is the learning objectives that include cognitive, affective, and psychomotor to achieve competence. Ethics earth is a concept that is integrated into the learning objectives and teaching materials. Understanding the concept of ethics earth covers translation, interpretation, and extrapolation (Bloom). Impact accompanist is a long-term goal that will be formed through a process of habituation in learning activities that the formation of a caring attitude and responsible behavior becomes a habit.

Instructional design is the support system model utilized in the syntax. A model support system includes three components, namely: (1) teaching materials developed from local wisdom and integrate ethics earth to analyze disaster mitigation and adaptation; (2) learning to use the media sources that are closely related to local wisdom and ethics of the earth; and (3) an assessment instrument to measure the achievement of learning outcomes and as a measure of the effectiveness of the model.

\section{CONCLUSION}

Standard content that includes competencies charged local knowledge on the subjects contained in geography class XI. Ethics earth is a charge that is integrated into the competence to analyze mitigation and adaptation to natural disasters. The learning model based on local wisdom to inculcate ethics earth consists of six components, namely: rationale, competence, syntax, learning outcomes, impact accompanist, and instructional design. Syntax consists of six steps: orientation, presentation of the material, identification of important concepts, understanding between concepts, application of concepts, and reflection. Inculcate ethics earth is measured through the understanding of the ethics of the Earth, including translation, interpretation, and extrapolation. Instructional design consists of three components: teaching materials, media and assessment.

\section{ACKNOWLEDGMENT}

On this occasion, the authors would like to thank to the committee ICSE UPI which has facilitated the publishing of the article. To Prof. Dr. Gurniwan Kamil Pasha and Prof. Dr. Enok Maryani, who has guided and validate the models.

\section{REFERENCES}

[1] Law of the Republic of Indonesia No. 20 Year 2003 on National Education System.

[2] Ningrum, E.. 2009. Kompetensi Profesional Guru dalam Konteks Strategi Pembelajaran. Bandung: Buana Nusantara.

[3] Trianto. (2009). Model-Model Pembelajaran Inovatif Berorientasi Konstruktivistik: Konsep, Landasan Teoretis-Praktis dan Implementasinya. Surabaya: Prestasi Pustaka.

[4] Syaodih, N. 1997. Pengembangan Kurikulum: Teori dan Praktik. Bandung: Remaja Rosdakarya

[5] Karli, H. 2002. Implementasi Kurikulum Berbasis Kompetensi Model Model Pembelajaran. Kumpulan model-model pembelajaran tidak diterbitkan.

[6] DePorter \& Mike Hernancki. 2007. Quantum Learning Membiasakan Belajar Nyaman dan Menyenangkan. Bandung: KAIFA.

[7] Whitherington, H.C. 1986. Teknik-Teknik Belajar dan Mengajar. Bandung: Jemmars.

[8] Keraf, A.S. 2006. Etika Lingkungan. Jakarta: Kompas.

[9] Daldjoeni, N. 1982. Pengantar Geografi Untuk Mahasiswa dan Guru Sekolah. Bandung: ALUMNI

[10] Hayati, S., dkk. (2011). Model Penanaman Nilai-nilai Kearifan Lokal pada Masyarakat Sunda dalam Membentuk Perilaku Lingkungan Bertanggung Jawab. Prosiding Konaspipsi ke I FPIPS UPI Bandung.

[11] Adimihardja, K. (2008). DinamikaBudaya Lokal. Bandung: Indra Prahasta.

[12] Gobyah, I. ,K. (2003). Berpijak pada Kearifan Lokal. Bali Pos. 4 September

[13] Permendikbud No. 64 of 2013 on the standard content

[14] Magnis, F. Suseno. 1993. Etika Dasar. Masalah-Masalah Pokok Filsafat Moral. Yogyakarta: Kanisius.

[15] Ningrum, E. 2015. Pembelajaran Berbasis Lingkungan Untuk Mengembangkan Kecerdasarn Ruang. Makalah disajikan pada Seminar Nasional Hari Bumi 22 April 2015 UPI Bandung.

[16] Arends, R.L. (1997). Classroom Instruction and Management. New York: Mc-Graw Hill.

[17] Undang Undang Republik Indonesia No. 20 Tahun 2003 tentang Sistem Pendidikan Nasional.

[18] Joyce, B., \& Weil,M. (1987). Models of Teaching. New Jersey: PrenticeHall, Inc. 